\title{
An Evaluation of Water and Land Uses in the Kano River Project, Phase I, Kano State
}

\author{
SANGARI, D U \\ Department of Geography, Nasarawa State University, Keffi, Nigeria
}

\begin{abstract}
The paper evaluates the use of water and land, as important irrigation components, in the Kano River Project, Phase I, based on the Kadawa Large-Scale Irrigation Project. The aim of the paper is to see whether project farmers apply irrigation water and cultivate land to the levels specified by the project management, in accordance with the original project design. The irrigation water requirements of wheat and tomatoes and the projected hectares were taken as standards to demonstrate farmers' effort in water application and land Development. An average water amount of $4627 \mathrm{~m}^{3} /$ ha was applied on wheat as against the recommended average of $6557.1 \mathrm{M}^{3} /$ ha. For tomatoes, an average water amount of $6933.9 \mathrm{~m}^{3} / \mathrm{ha}$ was applied as against the recommended average of $7139 \mathrm{M}^{3} / \mathrm{ha}$. Again, in terms of land development, an average of 1.1 hectares were under wheat cultivation as against 1.2 hectares devoted to tomato cultivation. The use of these important land development inputs, among others, has yielded an average of 2.0 tonnes per hectare per farmer as against the projected 2.6 tonnes of wheat. For tomatoes, an average yield of 34.5 tonnes per hectare per farmer was realized as against the projected 24.3 tonnes per hectare. It is argued that the observed improper water application and low land development are bound to pose serious limitations to efficient performance of the irrigation project, and, hence a threat to a sustainable irrigation development. @JASEM
\end{abstract}

In Nigeria, since the early seventies, demand for agricultural commodities has risen considerably which could not be met by the production system. Worse still the unprecedented emergence of the oil sector, among others, brought more neglect in the agricultural sector of the national economy. In consequence therefore, there has been a rise in the prices of agricultural products and high food bills (Sangari, 1996).

To salvage the unfortunate situation, attempts were made by the government to invest heavily in programmes that could result to the full realization of the agricultural potentials of the country. Among the attempts made was the development of our numerous water resources for irrigation and other uses. The development of large-scale irrigation projects in Nigeria came into prominence 20 years ago, during the Third National Development Plan Period. In 1976, eleven River Basin Development Authorities (RBDAs) were created to develop and manage irrigation for the production of crops and livestock (Hollis, et at, 1993).

In the northern part of Nigeria, irrigation is needed to provide water for year round agricultural production. The provision of irrigation water and land, among others, usually involves enormous financial expenses, as seen by the building of multi-million naira diversion dams, storage reservoirs, canals and other irrigation infrastructure. These irrigation components and infrastructure are provided with the aim of assisting farmers with the important scarce water resource, and, which has always been a fundamental agricultural limitation, in order to boost agricultural production (Abdulkadir, 1996 and Sangari 1996,
1997 and 2006). Because of the enormous expenses and sacrifices involved in large-scale irrigation projects, it is very important therefore for both irrigation water and land to be used wisely by farmers, in whose interest they are provided (Sangari, 1987 and Hollis, et al 1993).

This paper attempts to evaluate the operation of the Kano River Project, Phase I, based at Kadawa, with the aim of establishing if project performance matches project original objectives in terms of water and land uses. The water requirements of $5950 \mathrm{~m}^{3} / \mathrm{ha}$ and $6050 \mathrm{~m}^{3} / \mathrm{ha}$, recommended for wheat and tomatoes cultivation respectively in Nigerian savanna and the projected 22,000 hectares (HJRBDA, 1986) were taken to provide the standards against which the observed projected performance was evaluated.

Study area: The study area, which is part of the Kano River Project, Phase I, Kano state, is centred around the Kadawa Irrigation Project. The project, which began in 1965 as a pilot project, was one of the three original modern irrigation projects in the country; the others being the Bakolori Irrigation Project in Zamfara state and the South-Chad Irrigation Project in Borno State.

The Kano River project, which comprises of 62,000 hectares of irrigable land, is planned to be implemented in two phases. The first phase, which forms the study area, covers an area of 22,000 hectares of irrigable land and the second phase, based on the Hadejia Valley and Jama'a projects, cover an area of 40,000 hectares of irrigable land (HJRBDA). The project, lying on both sides of the Kano-Zaria and Kano-Rano roads originally started by the Kano 
State Government, is one of the largest irrigation projects in West Africa. The phase I of the project commenced operation in 1976 after it was formally taken over by the Hadejia-Jama-are River Basin Development Authority (HJRBDA) and was expected, according to the original design, to be completed by the end of 1982 . However, by 1978 about 4,000 hectares were completed and only 2,000 hectares of these were actually irrigated. So far a total of only 15,000 hectares have been developed for irrigation (HJRBDA, 1985).

The Kano River project is divided into two regions and each region is subdivided into sectors for administrative convenience. A sector is defined as an area receiving water through and off take in one of the branch canals. The size of the sector varies between less than 40 hectares and 2,800 hectares. Also the irrigated land area of the Kadawa irrigation sectoral project is sub-divided into a number of blocks and fields, each of which is being served by field channels. It is important to stress that water management in one sector is independent of other sectors and for implementation and management of the irrigation project, the physical subdivision of the project is as important as the administrative subdivisions. In the Kadawa village, there are 416 plots, totaling 214 hectares, and the average plot size per participating project farmers is 1.1 hectares (Sangari, 1987). However, with the privatization of the non-water components of the project by the Federal Government in 1991, the average size of irrigated plot was likely to fall below the observed average of 1.1 hectares.

The project area receives its irrigation water from Tiga Dam, 18 Kilometres upstream, and it lies in the loop of the Kano River as it turns North-East towards Lake Chad. The Dam has a storage capacity of 1,968 million cubic metres and a length of 6 kilometres. Water is supplied through the main canal by gravity to the project area, where the distribution network, comprising of branch canals, distributory canals and field channels take over.

\section{MATERIALS AND METHODS}

The procedure for the data collection involved two main stages; the pre-field and the field. The pre-field stage included a reconnaissance survey of the phase 1 of the Kano River Project, based at Kadawa. The Kadawa sector of the project was chosen for the study because it is the oldest. The field stage involved the actual data gathering and two methods were essentially used; the administration of questionnaires and measurements of the physical parameters of the project such as the sizes of irrigated landholdings, amounts of water applied and crop yields at the level of the participating project farmers. The questionnaire survey, applied to about 49 and 30 wheat and tomato farmers respectively for the purpose of detailed field investigation, was designed to contain and yield data on socioeconomic variables that tend to influence water application and land cultivation, such as farmers' education, length of time involved in irrigation practice, water availability, frequency of water application, conditions for water application, planting dates, access to land development inputs and motive of farming, among others.

The bucket system was employed in calculating the amounts of water applied by the sampled individual project farmers during the 1985/86 irrigation period. Under the bucket system, the flow of water through the syphons was collected in a container (bucket) of known volume (10 litres in the case of the bucket used) for a measured period of time, using a stopwatch. The container (bucket) was inserted into a dug pit and its surface was exactly at the same level with the surface of the irrigated plots in order to achieve evenness. With this, the rate of flow was measured by applying Michael's(1981) formula:

$\mathrm{D}=\mathrm{V} / \mathrm{T}$ where;

$\mathrm{D}$ is the discharge rate (litres/seconds)

$\mathrm{V}$ is the volume of the container (litres)

$\mathrm{T}$ is the time taken to fill (seconds)

The discharge rate was multiplied by the farmers' daily hours of water application. The observed daily amounts were multiplied by the frequencies of water application during the water application period to give the total amounts of water approximately applied by the project farmers. The total amounts of water applied were expressed in cubic meters and this was divided by the size of the farms (hectares) to give the actual amounts of water applied per hectare per irrigation period.

The projected 22,000 hectares and the actually developed hectareges were derived from the sources of the Hadejia-jama'are River Basin Development Authority (HJRBDA, 1985 and 1986). The percentages of the developed hectares were calculated in relation to the projected hectares. The expected crop yields of wheat and tomatoes were taken to provide the index for evaluating the performance of the project in terms of water and land uses, and to provide the standards against which the observed crop yields were evaluated. 


\section{RESULT AND DISCUSSION}

The Kadawa project of the Kano River Project, Phase 1 , typical of other large-scale irrigation projects in the Nigeria savanna, depends on water from an artificial reservoir (the Tiga Dam). About 95 per cent of the farmers lifted water from the field channels to their

Table 1: Indicators of period of water application

\begin{tabular}{lll}
\hline Indicators & \multicolumn{2}{c}{ Crops } \\
\cline { 2 - 3 } & Wheat & Tomatoes \\
& $\%$ of farmers & $\%$ of farmers \\
Dryness of crops & 2 & 63 \\
Dryness of soils & 85.7 & 27 \\
Seven days interval & 12.2 & 10 \\
& $\mathrm{~N}=40$ & $\mathrm{~N}=30$ \\
\hline
\end{tabular}

The dryness of the irrigated soils is often locally measured or seen by farmers in terms of the appearance of their footprints on the soils. Similarly, dryness of crops is measured in terms of wilting of crop stands. It is important to say that farmers, through long and accumulated irrigation experience, know exactly when these indicators of water application period are critical and so respond promptly to avoid loss in crop yields. The two indicators; dryness of soils and crops are related in the sense that dryness in soil conditions is often reflected in the condition of crops stands, especially tomatoes. Based on the foregoing, we may say that the conditions used for wheat cultivation under irrigation regime at the Kadawa project, as reflected by the proportion of the sampled farmers $(85.7 \%)$ may be said to be fairly an ideal condition for wheat water application (Table 1). This is because the need to keep adequate moisture in the soil for crop is the most important factor governing water application (Hansen, et al, 1978). Similarly, the leaf dryness observed for tomato irrigation (Table 1) may be said to be fairly an ideal condition for tomato water application. This is because dryness of crops is, among others, a direct consequence of lack of soil moisture. It then appears that the seven days interval of water application schedule, originally designed by the project planners, as seen in Table 1, was not a significant condition for water application.

The use of the dryness of crops and soils as water application indicators has profound influence on the frequently of water application. With the exception of 12.2 per cent and 10 per cent respectively of the wheat and tomato farmers, all others applied irrigation water at the frequency of twice per week to keep the frequently dried soils moist. It was observed that the soils often dried two or three days after water application. Again, the predominance of the observed twice per week frequency of water application at Kadawa project may not look strange because the farms using syphons while the remaining farmers used channel breaking. The period farmers applied water was more often than not influenced by some indicators, such as dryness of crops and soils, and the recommended seven days interval (Table 1).

period of investigation, which was the peak of irrigation practice in Kano Region, fell in the hottest months (March-May) when evaporation was high.

The rates of water application coupled with the irrigation period of the observed crops have considerably influenced the amounts of water applied. The average application amounts of $4608.6 \mathrm{M}^{3} / \mathrm{ha}^{-1}$ and $6933.9 \mathrm{~m}^{3} /$ ha for wheat and tomatoes respectively were applied as against the expected amounts of $5950 \mathrm{M}^{3} /$ ha for wheat and $6050 \mathrm{M}^{3} /$ ha for tomatoes. The results of water application, expressed as percentage required, show that 61 per cent of the wheat farmers under-applied water while the remaining 39 per cent over-applied by project standards. The corresponding figures for tomatoes were 60 per cent under-application and 40 per cent over- application.

The overall position of water application, as indicated by the observed individual water application as percentage of required, shows that none of the farmers had recorded optimal or expected level of water application on either of the two crops. The only attempt made to achieve water application close to the optimal level was perhaps on tomatoes, where 10 per cent of them applied 98 per cent of the expected water. This implies that wheat and tomato irrigation water application at the Kadawa project did not match the recommended practice, since the observed water application was not equal to the expected water application.

In trying to explain the inappropriate water applications, a variety of factors were isolated for discussion; the most important being the farmers' education, plot location and motive of cultivation. The results in Table 2 show that 8.2 per cent and 2 per cent of the educated wheat farmers applied water less than and in excess of the expected amounts respectively.

Table 2: Farmers' education and water application

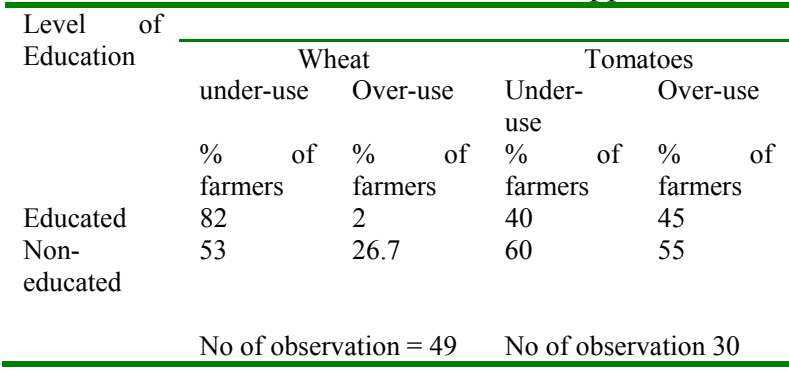


The results in Table 2 indicate that there seems to be no relationship between farmers' education and water application. None of the educated farmers had actually applied the expected amounts of water.

Furthermore, there seems to be a weak relationship between farmers' plot location and their water application (Table 3).

Table 3: Plot location and water application

\begin{tabular}{lllll}
\hline Location & \multicolumn{4}{c}{ Tomatoes } \\
\cline { 2 - 5 } & under-use over-use & under-use & over-use \\
& $\%$ of & $\%$ of & $\%$ of & $\%$ of \\
& farmers & farmers & farmers & farmers \\
Top enders & 40.8 & 34.7 & 40 & 30 \\
Bottom & 18.4 & 6.1 & 20 & 10 \\
enders & & & & \\
& & & & \\
& No of observation $=49$ & No of observation 30 \\
\hline
\end{tabular}

In both wheat and tomato cultivation, most farmers, especially those whose plots were located close to the field channels, under-applied water. One would have expected that because of the advantage of the relative closeness of their plots to main field channels, the top-enders would achieve over-water application. In Kadawa project, the under-water application was partly attributed to the farmers' low education (Table $2)$; improper knowledge of crop-water requirements, and, hence the low water application on wheat and tomatoes, relative to the expected project standards. However, what is called standard water application, from the point of view of the project design, may not necessarily be seen as standard conditions from the perspective of the farmers, who have been practicing water application long before the Kadawa project was conceived and implemented.

In addition, the harvest of tomatoes twice or more, with water application followed at each interval, explains the over-water application by 40 per cent of its cultivators. However, the economic profitability of tomato cultivation could not account for the underwater application by 60 per cent of its cultivators, but was rather explained by lack of proper knowledge of crop-water requirements. The experience of farmers, as reflected by the length of time they were involved in irrigation practice has been found to be insignificant in influencing the observed water application (Table 4).
Table 4: Length of time in irrigation practice and water application

\begin{tabular}{|c|c|c|c|c|}
\hline \multirow{4}{*}{$\begin{array}{l}\text { length of } \\
\text { time }\end{array}$} & \multicolumn{4}{|c|}{ Water application } \\
\hline & \multicolumn{2}{|c|}{ Wheat } & \multirow{2}{*}{$\begin{array}{l}\text { Tomatoes } \\
\text { under-use }\end{array}$} & \multirow[b]{2}{*}{ over-use } \\
\hline & under-use & over-use & & \\
\hline & $\begin{array}{l}\% \text { of } \\
\text { farmers }\end{array}$ & $\begin{array}{l}\% \\
\text { farmers }\end{array}$ & $\begin{array}{l}\% \text { of } \\
\text { farmers }\end{array}$ & $\begin{array}{l}\% \text { of } \\
\text { farmers }\end{array}$ \\
\hline Pre-1976 & 20.4 & 4.1 & 10 & 26.74 \\
\hline $\begin{array}{l}1976- \\
1985\end{array}$ & 32.7 & 22.4 & 13.3 & 10 \\
\hline \multirow{2}{*}{$\begin{array}{l}1985- \\
1986\end{array}$} & 8.2 & 12.4 & 36.7 & 3.3 \\
\hline & \multicolumn{2}{|c|}{ No of observation $=49$} & \multicolumn{2}{|c|}{ No of observation 30} \\
\hline
\end{tabular}

The results in Table 4 imply that the length of time in irrigation per cent was not a sufficient factor for proper water application. Thus, without close monitoring by the project management it would always be difficult for project farmers to apply water to crops to the proejct expected standards.

In terms of land developed by the project, available evidence suggests that by 1982, the year the project was supposed to be completed, only a total of 8,000 hectares of the projected 22, 000 hectares of irrigable land were actually developed (Table 5).

Table 5: Land Development (Hectares)

\begin{tabular}{lll}
\hline Period & $\begin{array}{l}\text { Hectares } \\
\text { developed }\end{array}$ & $\begin{array}{l}\text { Developed hectares } \\
\text { as \% of the Projected } \\
\text { Hectares* }\end{array}$ \\
\hline 1980 & 3000 & 16.4 \\
1982 & 8000 & 36.4 \\
1983 & 12000 & 54.4 \\
1984 & 14000 & 63.6 \\
\hline
\end{tabular}

* Projected hectares $=22,000$

Source: HJRBDA, 1985

The developed 8,000 hectares represent about 36.4 per cent of the projected hectarages. This was an increase over the 3,600 hectares developed in 1980 . Also about 63.6 per cent of the projected hectares were developed by the end of the 1984 cropping season (Table 5). Lack of funds for the acquisition of the necessary land development implements, among others, was found to account for the ability of the project management to develop all the projected 22,000 hectares in phase I.

During the period of investigation, which coincided with the 1986/87 irrigation season, it was found that only two serviceable tractors were available for land clearing and preparation, in addition to the only one hired excavator to clear water canals and field channels for effective water movement. These implements were indeed inadequate for the project, covering 22,000 hectares, and as a result only few 
participant farmers had their farms developed for irrigation production. The efforts of the authority were sometimes supplemented by contract services. Out of the 14,000 hectares developed, for example, 4,000 hectares of farm plots were prepared through direct labour while the remaining hactares were developed through Contract Services; 8,000 hectares and 2,000 hectares by the Netherlands Engineering and Construction Company (NEDECCO) and Taylor Woodrow respectively. The costs of irrigation materials and contractors' claims of idle hours, among others, make land devlopment operations very expensive. The high costs involved often make it difficult for the accruing benefits from the project to offset the cost of investment. Land development costs exceed forecast levels, implementation of construction design and as such level of development is below the projected level (Table 5). Sometimes, in addition to get many farm plots developed, land clearing and preparation operations were haphazardly and poorly done. The inability of the project management to level all the projected irrigable farm plots suggests that many farms were not actually developed for irrigation production, and this seriously undermined the realisation of the projcted crop yields. Similarly, farmers, especially wheat cultivators, who insisted on the uncertain mechanial development of their farm plots rather than manual development, commenced irrigation production late; after the planting dates. This may provide an additional reason for the low yield realised from wheat cultivation (Table 6).

Table 6: Crops cultivated

\begin{tabular}{llll}
\hline Crops & $\begin{array}{l}\text { Land } \\
\text { developed }\end{array}$ & $\begin{array}{l}\text { Yields } \\
\text { achieved }\end{array}$ & $\begin{array}{l}\text { Crop } \\
\text { income } \\
(\mathrm{N}) \text { tones }\end{array}$ \\
\hline Wheat & 7400 & 18500 & 8400000 \\
Tomatoes & 780 & 19500 & 1950000 \\
Source: HJRBDA, 1985 & & \\
\hline
\end{tabular}

The yield figures in Table 6 should be taken and used with caution since they reprsent official figures. From Table 6 it is clear that wheat appears to be the most important crop in the project in terms of the benefit of irrigation production. This perhaps explans why about 60 per cent of the developed land in the project were devoted to the cultivation of wheat alone. The remaining 40 per cent of the developed land were devoted to tomatoes and other crops. Studies by Sangari (1987) have revealed that the farmlands at the command of the participating project farmers were less than 1.5 hectares per farmer per irrigation season. The low land utilisation coupled with improper water application, among others, may account for the observed low yields of wheat and tomatoes (Table 7).

Table 7: Mean Crop yields (tonnes/ha)

\begin{tabular}{llll}
\hline Crops & Projected & Achieved & $\begin{array}{l}\text { Achieved as } \\
\text { \% projected }\end{array}$ \\
\hline Wheat & 2.6 & 2.0 & 77 \\
Tomatoes & 24.3 & 34.5 & 142 \\
\hline
\end{tabular}

Source: HJRBDA, 1986 and Sangari, 1987.

The mean yield of wheat achieved represents about 77 per cent of the projected mean per hectare per farmer, giving a yield gap of 0.6 tonnes per hectare per farmer. However, in the case of tomatoes, the achieved yield represents about 142 per cent of the projected mean yield, giving a mean surplus of 10.2 tonnes per hectare per farmer (Table7).

The resulting yields of wheat ant tomatoes reflect some of the effects of the performance of the project in terms of land and water uses, among others, on the participating projetc farmers. It is beielved that project, such as Kano River Project, consist of complex innovations, which require a lot of time for the farmers to study, understand and implement correctly. One of such apparent innovations relates to the cropping patterns. The project prefered wheat to tomatoes, while participating project farmers prefered tomatoes mainly to wheat. Because of the interest of the project management in wheat cultivation, more than 86 per cent of the total hectares cultivated were devoted to wheat alone (Table 6). Although more hectares were devoted to wheat than tomatoes, for instance, the resulting crop yields of tomatoes far exceeded that of wheat both at the levels of the project's estimates (Table 6) and the average farmers' estimates (Table 7).

In tems of labour intensity, that is relationship between crop yield and hectares cultivated, of the two crops, there tends to be variations. Table 8 gives the labour intensity of tomato cultivation as 25 tonnes per hectare as against 2.5 tonnes per hectare for wheat.

Table 8: Labour intensity

\begin{tabular}{llll}
\hline Crops & $\begin{array}{l}\text { Hectare } \\
\text { cultivated }\end{array}$ & $\begin{array}{l}\text { Yield } \\
\text { achieved } \\
\text { (tonnes) }\end{array}$ & $\begin{array}{l}\text { Yield/hectare } \\
\text { (tonnes) }\end{array}$ \\
\hline Wheat & 7400 & 18500 & 2.5 \\
Tomatoes & 780 & 19500 & 25 \\
\hline
\end{tabular}

Source: Derived from table 6.

Furthermore, what gives farmers anticipated crop yields are their agronomic management practices, often dictated by, among others, the economic profitability of their crops. It was observed during the period of investigation that tomatoes was priced more 
than wheat, in terms of their economic values. While the government guranteed minimum price for the 1986/87 irrigation season for wheat was N1,125 per hectare (that is $\mathrm{N} 450$ per tonne $=\mathrm{N} 450 \mathrm{x} 2.5$ tonnes), the price for tomatoes was N3,200 per hectare (that is N160x20tonnes).

In addition to its economic profitability, tomato cultivation under effective irrigation management can result to double and sometims triple cropping season, with the resultant increase in crop yield, and, hence high income. These reasons were predominant in explaining the farming psyche of the participating project farmers in devoting more attention to tomato cultivation in spite of the low level of land development and allocation to its cultivation (Table 8 ). It should be mentoned that the strategy of largescale irrigation project has increased greatly the penetration of commercial farming into the rural areas, forcing farmers to grow crops for sale in order to make profit.

Again, some of the administrative decisions made at the farm level are sometimes in conflict with the project goals. It was observed during the period of investigation that the project management in order to make water available at the Hadejia sector of the project (downstream), ordered for the release of water indiscriminately. The consequence of this was improper water use, with its resultant effects of water logging and erosion of the already developed farm plots. These rendered many of the developed farm plots out of production, leading to the realization of crop yield level far below what was projected, especially for wheat (Table 7). Since wheat was considered a project crop, as already hinted, sectors planted with wheat received more irrigtion and other farming resources than sectors planted with other crops. Therefore, it was likely that the improper use of water and its effects were felt more in the wheat sectors.

Conclusion: In conclusion, we may say that the result of water and land uses at the Kadawa irrigation sector of the Kano River Project contradicts the principle that careful water and land utilization involves considerable degree of expertise and knowledge so that enough water would be provided to the land to satisfy the needs of crops (Cantor, 1970 and Jackson, 1977). From the results, one would say that the Kadawa project illustrates a fact, which conforms to Cantor's (1970) observtion that too often in developing countries project farmers are inadequately prepared for the advent of much larger supplies of irrigation water than they had hitherto dreamed possible. In consequence, farmers are faced often with day-to-day problem of how to apply the expected water to land in order to generate the expected yield benefits per irrigation period.

The improper water application, due to conflicting interests of project management and project beneficiaries and the serious institutional problems, have made the project to operate at low productivity level. This is clearly demonstrated in terms of the projected land that have already been developed for irrigation and the accruing crop benefits. Finally, the observed low level of land and water uses, which had affected the performance of the project could seriously lead to it's entire collapse. It must be stressed here that the conflict of choice between farmers' preference of tomato to wheat production and the project preference of wheat to tomato would continue to lead to low water and land uses. The effective resolution of the observed crisis lies in the fact that farmers preference of tomato cultivation to wheat should be respected, and thus access to water should be the same to all crops, other than the project prefered wheat.

Similarly, the practice of seven-day frequency of water release to farmers by the project management should be reversed to allow water release to conform only with farmers' demands. Farmers, it was observed, seem to know, through accumulated irrigation practices and, thus experience, when crops need water, and, hence when to apply it. This would enhance interest of the participating farmers in the project and would, in response, ensure greater and effective uses of both land and water.

Worst still the privatization of the non-water components of irrigation, such as land development, coupled with the fact that water supplies are still managed by the authority, could worsen the already observed low performance. There is the need for the government and participating project farmers to ensure that land and water inputs are carefully and wisely utilised for optimum and sustained irrigation performance.

\section{REFERENCES}

Abdulkadir, A (1996). A Comparative water management problems in the South-Chad and Kadawa Sector of the Kano River Irrigation Project, Nigeria. Journal of Social and Management Studies. Vol. 3,83-98.

Cantor, L M (1970) A World Geography of Irrigation. Edinburgh: Robert Cunnigham \& Sons. 
Hadejia-Jama'are River Basin Development Authority (1985) A Brief on the Kano River Project, Phase I.

Hadejia-Jama'are River Basin Development Authority (1986). Activities of the Hadejiajama'are River Basin Development Authority, Kano

Hansen, V E, et al (1978). Irrigation Principles and Practices, $4^{\text {th }}$ edition. New York : John Wiley \& Sons.

Hollis, G E, Adams, W M and Aminu Kano, M (1993). The Hadejia-Nguru Wetlands. Environment, Economy and Sustainable Development of a Sahelian Floodplain Wetland, IUCN.

Jackson, I J (1977) Climate, Water and Agriculture in the Tropics. Longman.

Michael, A M (1981) Irrigation. Theory and Practice. Vikas
Sangari, D U (1987). An Evaluation of the utilisation of some farming inputs at the Kadawa LargeScale Irrigation Project, Kano state. An unpublished M.Sc. thesis. Department of Geography, Bayero University, Kano.

Sangari, D U (1993). Land Development in Nigeria. The Dala Geographer, Vol. 8, 53-61. Department of Geography, Bayero University, Kano

Sangari, D U (1996) Characteristics and Problems of Sustainable Fadama Development in Northern Nigeria. Journal of Social and Management Studies. Vol. 3. 114-127. Bayero University, Kano.

Sangari, D U (1997). Fuel Scarcity and Small Scale Fadama Irrigation Development in Kano Region. Falola, J.A et al (eds). Issues in Land Administration and Development in Northern Nigeria. 253-260. Bayero University, Kano.

Sangari, D U (2006). Traditional Flood Recession Farming in Donga River Basin, Taraba State. Nigerian Journal of Tropical Geography. 1 (1), 52-57. Nasarawa State University, Keffi. 